\title{
Zmiana wizerunku miasta w świetle likwidacji hałd pohutniczych
}

\section{Marta Bożym}

\section{STRESZCZENIE}

W artykule przedstawiono zmiany w krajobrazie miasta Ozimek (woj. opolskie) dotyczące terenów przemysłowych, powstałe w wyniku likwidacji hałd przyzakładowych. Podjęcie tematu przez autora jest wynikiem wieloletniej współpracy z opisanym zakładem przemysłowym, w ramach której badano wpływ odpadów zgromadzonych na hałdach na środowisko naturalne oraz fakt, że autor artykułu jest mieszkańcem opisywanego miasta. Głównym celem opracowania było przybliżenie przykładu zmian w krajobrazie miejskim terenów postindustrialnych wynikające z likwidacji hałd przemysłowych. Jest to przykład racjonalnego zarządzania obszarem miejskim i dobrej współpracy jednostek samorządowych z przemysłem. Likwidacja hałd oraz rewitalizacja terenów poprzemysłowych wpłynęła nie tylko na poprawę krajobrazu, ale także na środowisko naturalne. Dzięki ponownemu wykorzystaniu odpadów zgromadzonych na hałdach ograniczone zostało zużycie surowców naturalnych i jednocześnie zmniejszono ich wpływ na środowisko. Dwie hałdy należące do „Huty Małapanew” zlokalizowane były w poprzek drogi krajowej nr 46 Opole-Warszawa (DK46), wzdłuż przepływającej tam rzeki Mała Panew. Przez wiele lat hałdy stanowiły integralną część miasta, tworząc industrialny krajobraz. Obecnie tylko niewielka część składowiska należy do zakładu, gdzie gromadzi się odpady z bieżącej produkcji. Pozostałą część składowisk sprzedano firmie zajmującej się odzyskiem odpadów hutniczych i produkcją kruszyw drogowych. Dzięki stopniowej likwidacji hałd, krajobraz miasta ulega ciągłej poprawie. Gmina odzyskała część terenu składowiska, którą przeznaczyła pod inwestycje. W pracy opisano genezę powstania składowisk i ich rozbudowę na tle historii zakładu. Dodatkowo zilustrowano zmiany krajobrazu miejskiego w trakcie likwidacji hałd.

Słowa kluczowe: odpady przemysłowe, hałdy przyzakładowe, krajobraz miejski

\section{Historia Huty Małapanew (Ozimek, woj. opolskie)}

Historia powstania huty związana jest z rewolucją przemysłową która rozpoczęła się w Anglii pod koniec XVII w. oraz potrzebami wojsk walczących w wojnach toczących się w Europie. Do najważniejszych kryteriów lokalizacji zakładów przemysłowych zaliczano czynniki naturalne, związane głównie z występowaniem surowca, zasobami wodnymi i zapleczem energetycznym. Początkowo fabryki uzależnione były od wód płynących, napędzających koła młyńskie, lokalizowane były wzdłuż rzek na terenach wiejskich. Przełomem było wykorzystanie maszyn parowych, które uniezależniły produkcję od warunków naturalnych [Juzwa 2010].

Huta powstała w 1754 r., kiedy to król pruski Fryderyk II podjął decyzję o budowie huty w okolicach Krasiejowa na Śląsku Opolskim. O lokalizacji zakładu zdecydowała konieczność dostarczania broni wojskom pruskim walczącym na Śląsku, ponieważ dostawy $\mathrm{z}$ hut Brandenburgii były trudne logistycznie i bardzo kosztowne. Za wyborem terenu 
pod budowę zakładu przemawiało bogactwo tutejszych gruntów w surowiec, czyli rudę darniową. Poza tym zaletą była możliwość pozyskiwania drewna z okolicznych lasów oraz bliskość rzeki Mała Panew. Dzięki rosnącym potrzebom wojska rozwój huty był bardzo szybki. Pracownicy zatrudnieni w hucie pochodzili głównie z Niemiec i Czech. Szkolono także okolicznych mieszkańców. Zatrudnianie ludzi pochodzących z terenów rolniczych ograniczało tempo postępu technicznego. Głównym kierunkiem przyspieszenia rozwoju przemysłowego było kształcenie zawodowe. Powstającym szkołom towarzyszyła konieczność zapewnienia miejsc zamieszkania uczniom i pracownikom. Powstawały osiedla pracownicze, zwane patronackimi, budowane przez właścicieli zakładów przemysłowych [Juzwa 2010].

Huta początkowo produkowała militaria, specjalizowała się w wytwarzaniu amunicji. Początkowo głównym napędem urządzeń hutniczych były koła napędowe zasilane wodą z pobliskiej rzeki, której koryto uregulowano w 1821 r. [Juros 2010]. W celu zwiększenia przepływu wody w głównym korycie rzeki, zasypano niektóre kanały. Konsekwencje odczuwalne są do dnia dzisiejszego. Posadowione w starym korycie rzeki budynki przechylają się i wymagają ciągłej kontroli z powodu zapadania gruntu. W 1779 r. „Królewska Huta Malapane" (jak ją wówczas nazywano) przeszła pod administrację Wyższego Urzędu Górniczego, co miało decydujący wpływ na dalszy rozwój zakładu oraz pobliskiej osady. Dzięki zastosowaniu najnowszych zdobyczy techniki zwiększono i poszerzono zakres produkcji. W wyniku działań wojennych, podczas trwania wojen napoleońskich, huta stała się głównym, lokalnym producentem armat. W kolejnych dziesięcioleciach produkcję poszerzono o inne wyroby stalowe i żeliwne. W 1834 r. za sprawą króla Prus, Fryderyka Wilhelma III, został utworzony Niemiecki Związek Celny, który zapoczątkował zjednoczenie Niemiec, które zakończyło się w 1871 r. po wygranej wojnie niemiecko-francuskiej. Na tempo uprzemysłowienia Niemiec wpłynęła wysoka kontrybucja wojenna. Zakłady przemysłowe miały zapewniony rynek zbytu, jakim była armia, potrzebna do utrzymania militarnej potęgi państwa [Juzwa 2010]. Na przełomie XIX i XX w. w wyniku rozwoju technologii odlewniczych, w hucie wymieniono stare piece na nowe o zwiększonej wydajności. Powstały także znane do dzisiaj piece martenowskie. Huta wówczas produkowała części do maszyn parowych, cylindrów, kół, łańcuchów, mostów, filarów, krat i innych. Ciekawostką jest, że pierwsza maszyna parowa na Śląsku powstała właśnie w Hucie Małapanew w 1794 r. Huta specjalizowała się także w produkcji elementów służących do budowy mostów żeliwnych. Muzeum hutnictwa, zlokalizowane przy zakładzie, prezentuje osiągnięcia zakładu w produkcji mostów z końca XVIII i początku XIX w. Na terenie miasta znajduje się najstarszy w Europie i jednocześnie na świecie (1827 r.), wiszący most żeliwny (fot. 1), który jest chlubą zakładu i całej gminy. Dzięki współpracy z pracownikami Politechniki Opolskiej niedawno most odrestaurowano i obecnie stanowi atrakcję turystyczną miasta. Ciekawostką jest, że budynek widoczny na fotografii 1., to biurowiec wybudowany w latach 70. i oddany w latach 80. XX w. Wybudowano go w latach świetności huty, kiedy planowano podwojenie produkcji i zarazem wielkości zakładu. Przez wiele lat stanowił jedynie zagrożenie i był reliktem przeszłości. Został wyburzony w sierpniu 2017 r. 


\section{Fot. 1. Najstarszy żeliwny most wiszący wyprodukowany w Hucie Małapanew w Ozimku}

\section{a. stan w 2012 r.}

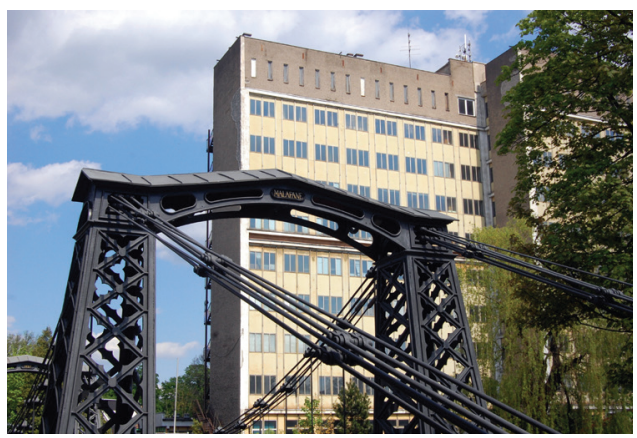

Fot. M. Bożym

\section{b. stan po wyburzeniu biurowca w 2017 r.}

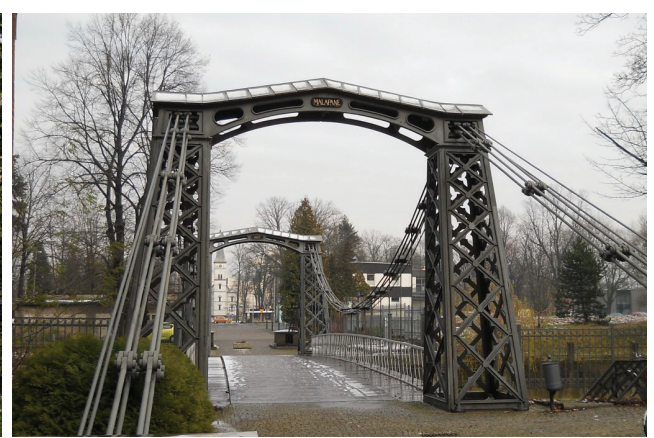

W 1791 r. w hucie przy produkcji odlewów po raz pierwszy zastosowano formowanie z wykorzystaniem piasków formierskich. Była to nowatorska metoda zaadaptowana z Anglii. Technologia ta jest stosowana do dzisiaj. Jej wadą jest powstawanie znacznych ilości odpadów. Szacuje się, że na tonę wyprodukowanych odlewów powstaje jedna tona odpadów. Początkowo zużyte masy formierskie składowano obok zakładu, bezpośrednio na gruncie. Dalszy rozwój huty i zmiany kierunku produkcji wymusiły na zarządzających sprowadzanie fachowców z odległych zakątków Europy, co w konsekwencji przyczyniło się do powstania przyzakładowych szkół zawodowych. Wybuch I wojny światowej początkowo spowodował problemy produkcyjne, gdyż większość pracowników dostała powołanie do wojska. Jednak zapotrzebowanie na broń spowodowało dalszy rozwój zakładu. Po I wojnie rozbudowywano hutę. Uruchomiono pierwsze piece elektryczne, co znacznie poprawiło jakość powietrza wokół zakładu. Lata 20. i 30. XX w., to systematyczny wzrost produkcji na potrzeby szybko rozwijającej się niemieckiej gospodarki, również zbrojeniowej. W trakcie II wojny światowej hutę rozbudowano, wykorzystując niewolniczą pracę jeńców wojennych wielu narodowości. Produkcja w hucie trwała do ostatnich dni wojny, aż do momentu wkroczenia wojsk radzieckich. Po II wojnie, dzięki dalszemu rozwojowi zakładu, rozbudowywano także miasto Ozimek. Historia miasta rozpoczyna się od powstania osiedla pracowniczego przy osadzie Huttendorf, która w 1910 r. liczyła 664 mieszkańców, w 1933 - 1205, a w 1939 4000 mieszkańców. W 1928 r. utworzono gminną strukturę o nazwie Malapane, do której włączono osiedla hutnicze i osadę Huttendorf. Nazwę Ozimek miejscowość otrzymała po II wojnie światowej, w 1954 r. Ozimek posiadał status osiedla, a w 1962 r. otrzymał prawa miejskie [www.ozimek.pl]. Zatrudnienie w 1912 r. to 725 robotników, a w 1913 już 820. Natomiast w latach 30. XX w., w czasie trwania kryzysu ekonomicznego, bezrobocie sięgnęło 50\%, a zatrudnienie spadło do nieco ponad 200 robotników [Juros 2010]. W $1945 \mathrm{r}$. na wyposażeniu zakładu były 4 piece stalownicze, a w $1954 \mathrm{r}$. funkcjonowało ich już 11 . Po II wojnie światowej do huty sprowadzono wykwalifikowanych pracowników z odległych zakątków kraju. Zatrudnienie w 1950 r. wynosiło 4297 pracowników, w 1955 - już 5776, w 1965 - 6011, a w 1975 r. aż 7052 [Popiołek 1955; Juros 2010]. 
Zmiany gospodarcze, jakie nastąpiły po 1989 r. spowodowały konieczność dostosowania produkcji huty do potrzeb gospodarki rynkowej. W minionym trzydziestoleciu, $\mathrm{tj}$. od 1990 r., doszło do restrukturyzacji zakładu. Powstały jednoosobowe spółki takie jak Małapanew - Maszyny i Konstrukcje; Małapanew - Armatura; Małapanew - Modelarnia i Małapanew - Zakłady Odlewnicze. Od 2004 r. Huta przynależy do grupy kapitałowej GWARANT [www.ozimek.pl], która przywróciła historyczną nazwę Huta Małapanew Sp. z o.o. Po wejściu Polski do Unii Europejskiej Huta Małapanew, podobnie jak inne zakłady przemysłowe, musiała spełnić rygorystyczne wymagania środowiskowe. Już w latach 90. XX w. podjęto przedsięwzięcia w zakresie ochrony powietrza. Przyczyniło się to do ponad dwukrotnego zmniejszenia stężenia opadu pyłu oraz redukcji pozostałych zanieczyszczeń w powietrzu. Na poprawę jakości powietrza miała wpływ nie tylko modernizacja urządzeń oczyszczających, ale także zmniejszenie produkcji. Huta postawiła sobie cele dotyczące zmniejszenia uciążliwości jakie stwarzają stałe odpady poprodukcyjne, zgromadzone na dwóch hałdach przyzakładowych, tzw. „Starej” i „Nowej hałdzie” [Baginska 2008].

\section{Powstanie hałd}

Odpady hutnicze gromadzono na dwóch hałdach zlokalizowanych na północny zachód od terenów mieszkalnych Ozimka. Huta do końca lat 80. XX w. wytworzone odpady w całości deponowała na tych składowiskach. Najstarsza cześć składowiska zlokalizowana była

Fot. 2. Widok na miasto Ozimek z zaznaczoną Hutą Małapanew i dwoma składowiskami odpadów (hałdą "Starą" i „Nową"). W tle Jezioro Turawskie

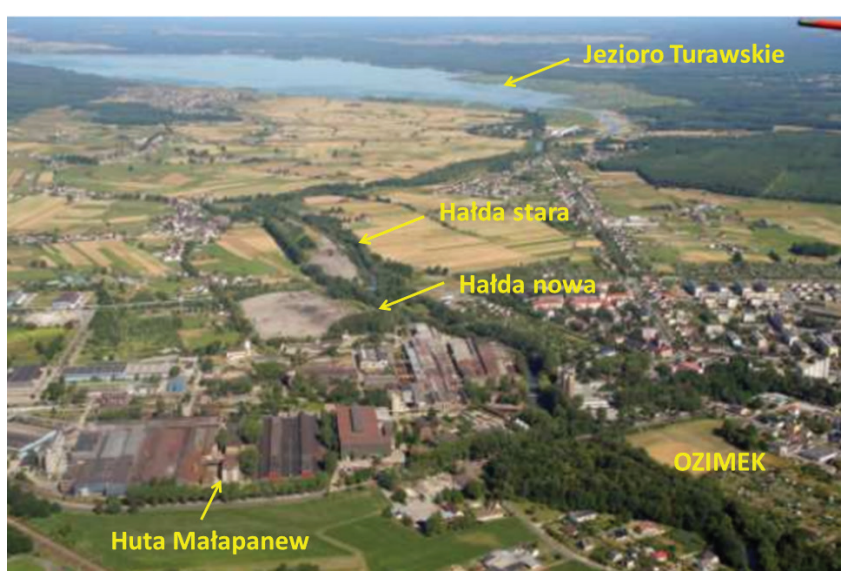

Źródło: www.ozimek.pl, 2016 w bezpośrednim sąsiedztwie hali produkcyjnych. Obecnie (2017 r.) odpady tam zgromadzone, są odzyskiwane i wykorzystywane do produkcji kruszyw drogowych. Właściwe składowiska powstały na specjalnie przygotowanych podłożach, które uszczelniono warstwą trudno przepuszczalnych iłów. Wykonano obwałowanie i rów opaskowy zagłębiony na około 2 m wokół hałd poniżej powierzchni terenu. Obecnie wody opadowe i odciekowe ze składowiska zbierane są w kolektorze odwadniającym, co uniemożliwia zanieczyszczenie wód gruntowych. Poprzez nasadzenie roślinności od zachodniej i północnej strony obu hałd ustanowiony został pas ochronny. Ostatecznie powstały dwa wyodrębnione przestrzennie składowiska - potocznie zwane „Starą" i „Nową hałdą” (fot. 2). 
W latach 1954-1984 odpady deponowane były na tak zwanej "Starej hałdzie”, zlokalizowanej po drugiej stronie drogi nr 46 niż zakład. Odpady na hałdzie "Nowej" deponowane są od 1985 r. do dzisiaj. W celu likwidacji odpadów zdeponowanych na obu hałdach, w 1996 r. huta rozpoczęła współpracę z firmą BEHATEX z Częstochowy. W konsekwencji w sierpniu $1997 \mathrm{r}$. podpisano umowę dotyczącą przerabiania odpadów. Efektem współpracy były liczne inwestycje BEHATEXU $\mathrm{w}$ instalacje przerobowe (fot. 3 i 4). W tym czasie BEHATEX badał kierunki i możliwości zastosowania przerobionych odpadów w budownictwie i drogownictwie. Odpady były wykorzystywane przy budowie dróg. Ciekawostką jest, że znaczne ilości kruszywa wykorzystano pod budowę obwodnicy Opola. W wyniku długoletniej współpracy

\section{Fot. 3. Widok z hałdy „Starej" na Ozimek}

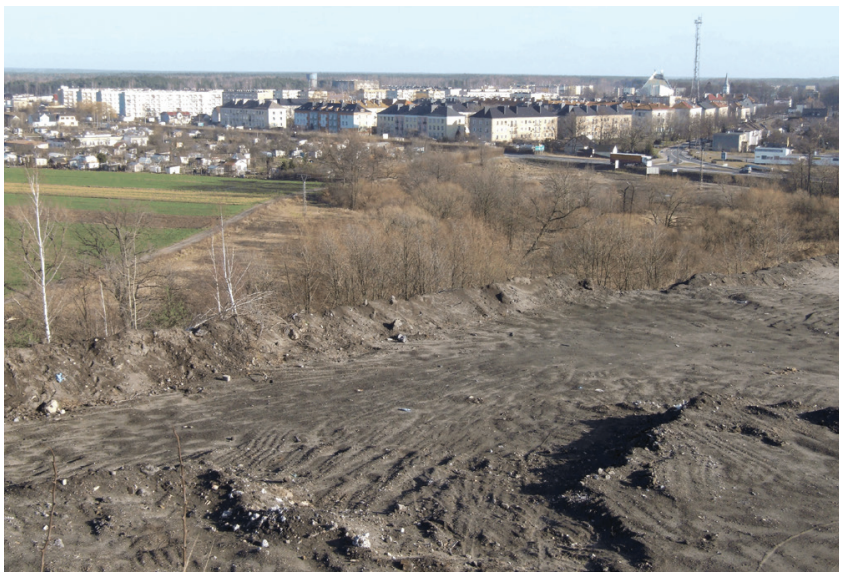

Fot. M. Bożym 2008

\section{Fot. 4. Eksploatacja hałdy „Starej” przez firmę}

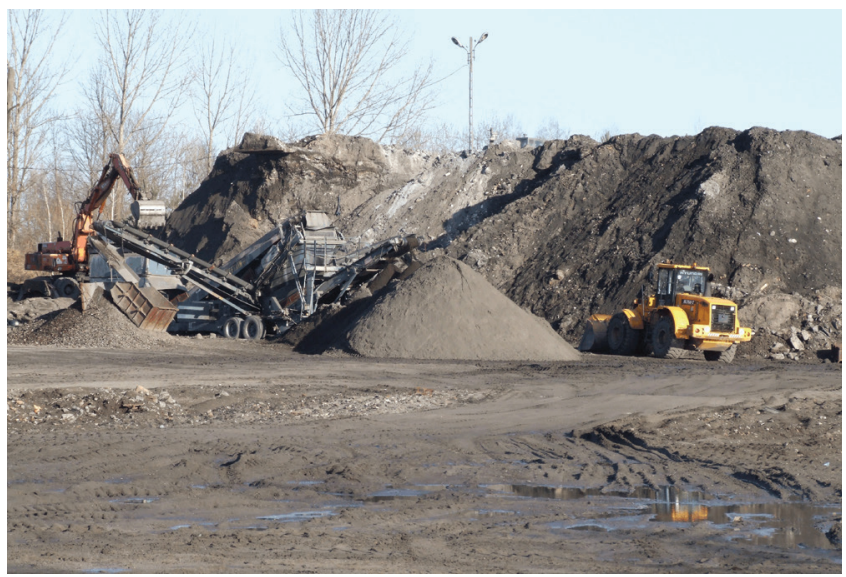

Fot. M. Bożym 2012 z huta, w 2005 r. firma BEHATEX zdecydowała się zakupić teren "Starej hałdy”. Równocześnie firma prowadziła odzysk odpadów na drugiej części składowiska, tj. „Nowej hałdzie”, należącej wciąż do huty.

Oba zwałowiska miały kształt nieforemnych pryzm, o długości do 900 m, szerokości wierzchowiny $10-40$ m oraz wysokości 30-40 m. Nachylenie skarp wynosiło 35-45 ${ }^{\circ}$. W wyniku eksploatacji obie hałdy wielokrotnie zmieniały swój kształt i wymiary (fot. 5 i 6). Większą część terenu po eksploatacji składowiska „Nowa hałda” sprzedano gminie, która podzieliła go na działki inwestycyjne. Obecnie trwają prace nad zagospodarowaniem i rewitalizacją tego terenu. Dzięki takim działaniom podróżujący trasą Opole-Warszawa nie widzą już dwóch hałd, które przez dziesięciolecia „witały” przejeżdżających przez Ozimek. Fotografie 5. i 6. przedstawiają zmiany kształtu i wielkości obu hałd w latach 2004-2017. W zestawie 
54 | ZMIANA WIZERUNKU MIASTA W ŚWIETLE LIKWIDACJI HAŁD POHUTNICZYCH Marta Bożym

Fot.5.Zmiany wielkości zwałowiska odpadów, potocznie zwanego "Starą hałdą", zlokalizowanego po lewej stronie drogi DK46 na trasie Opole-Warszawa

a. Widok z trasy DK46 od strony Opola, zima 2004 r.

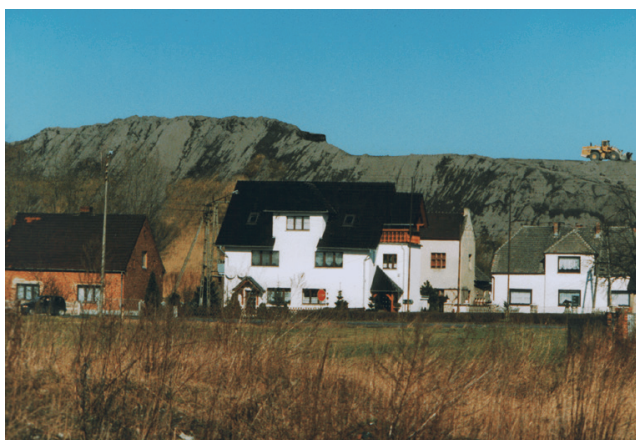

Fot. M. Bożym

c. Widok z trasy DK46 od strony Opola, wiosna 2012 r.

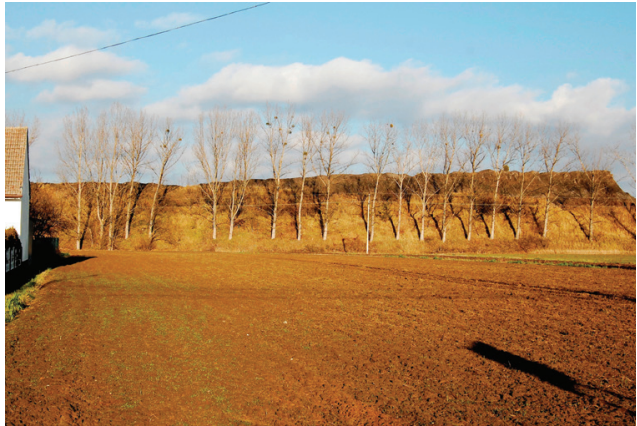

Fot. M. Bożym

e. Widok z trasy DK46 od strony Opola, wiosna 2016 r.

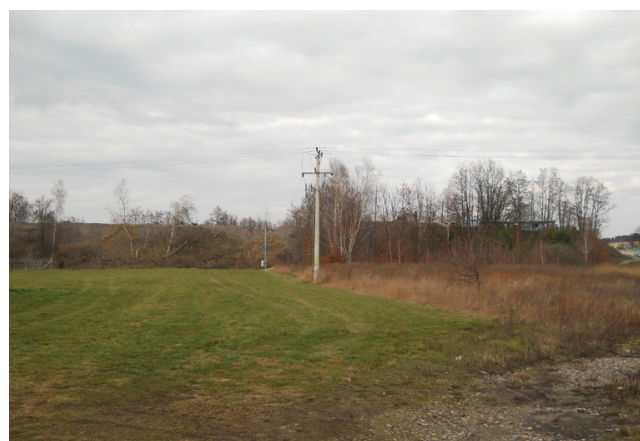

Fot. M. Bożym b. Widok od strony rzeki, zima 2004 r.

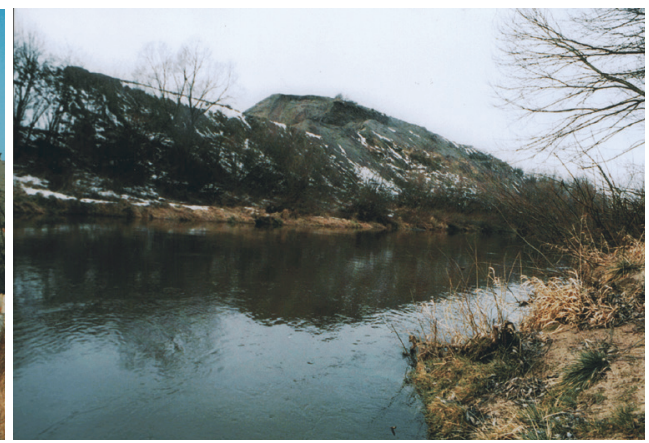

Fot. M. Bożym

d. Widok od strony rzeki, wiosna 2012 r.

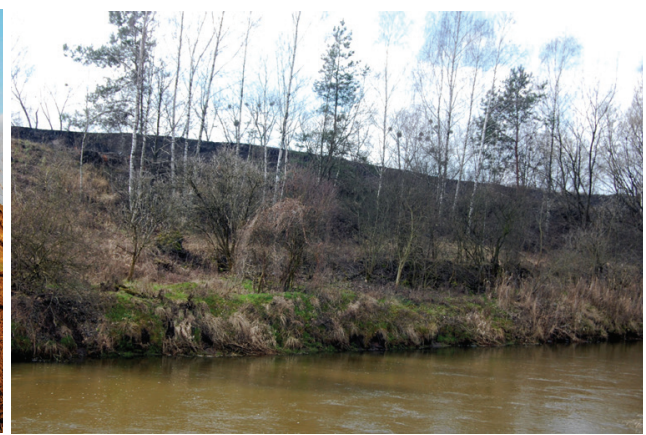

Fot. M. Bożym

f. Widok od strony rzeki, wiosna 2016 r.

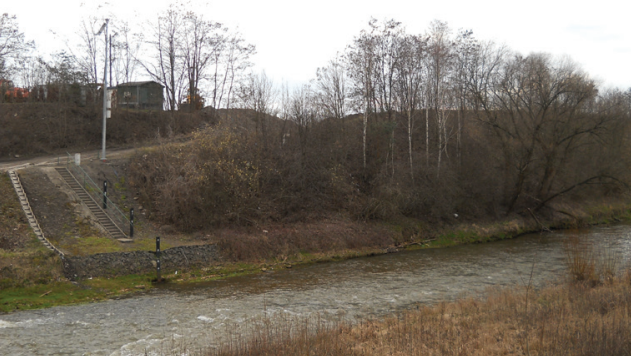

Fot. M. Bożym 


\section{g. Widok z trasy DK46 od strony Opola,} lato 2017 r.

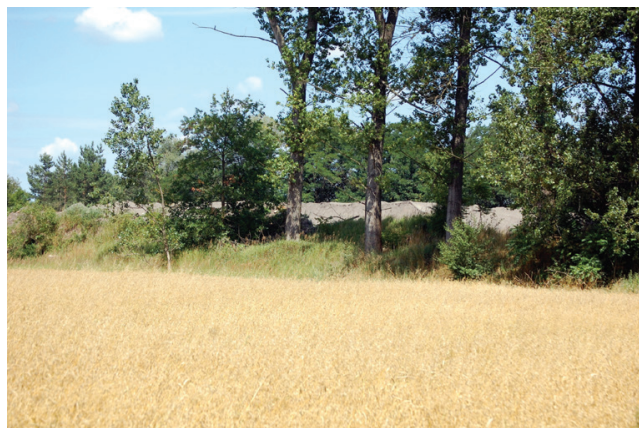

Fot. M. Bożym

\section{h. Widok z mostu, lato 2017 r.}

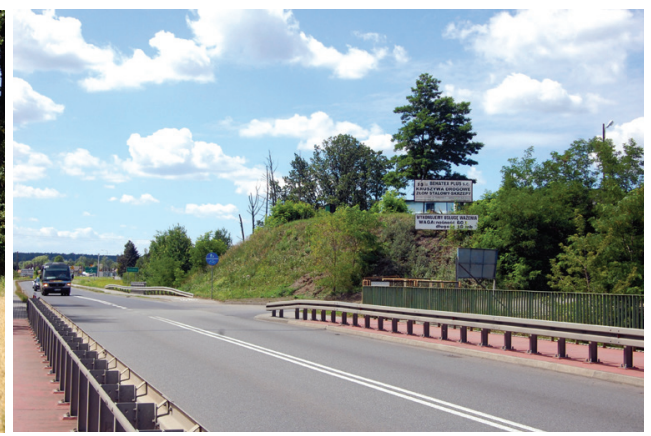

Fot. M. Bożym

fotografii zebrano te najbardziej zbliżone, wykonywane z dwóch stron: od strony rzeki i po przeciwnej stronie. Wały oddzielające obie hałdy od rzeki nie zostaną zlikwidowane ze względów bezpieczeństwa. Na fotografiach 5 a-h przedstawiono zmiany kształtu i wielkości "Starej hałdy" w czasie, tj. od 2004 r., czyli momentu rozpoczęcia eksploatacji do lipca 2017 r. Na hałdzie tej prace wciąż trwają. Początkowo nie było widać zmian kształtu tej hałdy, gdyż eksploatację prowadzono wewnątrz zwałowiska. Na fotografii 5 a widoczna jest tzw. „Stara hałda" w momencie rozpoczęcia eksploatacji w 2004 r., z widoczną koparką na szczycie. Zdjęcie wykonano od strony zabudowań, jadąc z Opola w kierunku Warszawy. Natomiast zdjęcie $5 \mathrm{~b}$ przedstawia stan tej samej hałdy od strony rzeki. Kolejne zdjęcia przedstawiają „Hałdę starą" w 2012 r., od strony pól za domostwami, znajdującymi się na poprzednim zdjęciu (5 a). Stan zwałowiska w 2016 r. przedstawiają fotografie 5 e i f. Faktyczne zmiany w wielkości tej hałdy można zauważyć porównując fotografię 5 c (2012 r.) i 5 g (2017 r.). Na fotografiach $5 \mathrm{f}$ i 5 h przedstawiono wjazd na składowisko, gdzie samochody ciężarowe odbierają odpady. Ta część hałdy prawdopodobnie zostanie zlikwidowana po zakończeniu jej eksploatacji. Fotografia 5 h przedstawia stan najnowszy, z widoczną częścią mostu, nad którym wcześniej znajdował się wiadukt kolejowy, łączący obie hałdy. Na fotografiach 6 a-h przedstawiono zmiany kształtu i wielkości „Nowej hałdy” w latach 2004-2017. Pierwsze dwie fotografie (fot. 6 a i b) przedstawiają stan w 2004 r., w trakcie eksploatacji. „Hałda nowa" zlokalizowana była bliżej zakładu, po prawej stronie drogi DK46 jadąc od Opola. Największe zmiany można było zauważyć w tej części składowiska, gdyż prowadzona eksploatacja spowodowała szybkie zmniejszenie ilości składowanych tam odpadów. Po zrównaniu poziomu hałdy z gruntem, część terenu huta przekazała gminie (fot. 6 c, d, e i g). Pozostałą część składowiska, na której gromadzi się odpady bieżące, oddzielono od części inwestycyjnej i ogrodzono. Widoczne zwałowiska na dalszym planie (fot. $6 \mathrm{~g}$ ), to zgromadzona część grubszej frakcji odpadów, które oddzielają składowisko od rzeki, co jest także widoczne na fotografii $6 \mathrm{~h}$. 
Fot.6.Zmiany wielkości zwałowiska odpadów, potocznie zwanego "Nową hałdą", zlokalizowanego po prawej stronie drogi DK46 na trasie Opole-Warszawa

a. Widok z trasy DK46 od strony Opola, zima 2004 r.

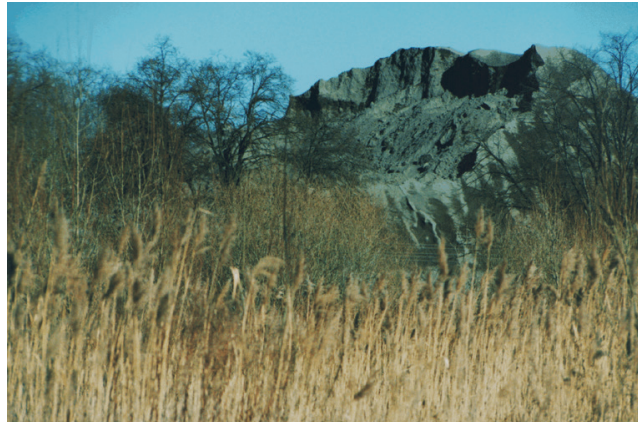

Fot. M. Bożym

c. Widok z trasy DK46 od strony Opola, wiosna 2012 r.

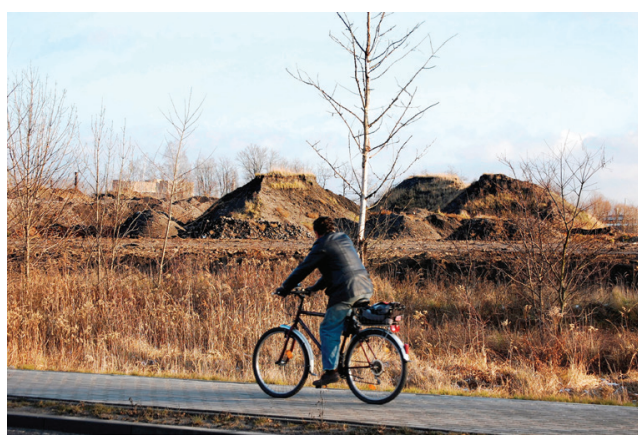

Fot. M. Bożym

e. Widok z trasy DK46 od strony Opola, wiosna 2016 r.

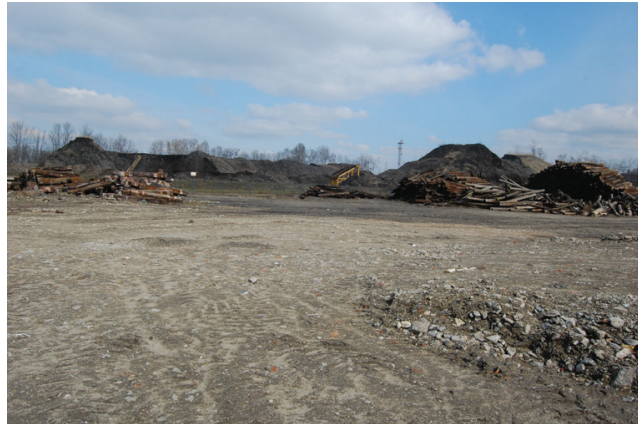

Fot. M. Bożym b. Widok od strony rzeki, zima 2004 r.

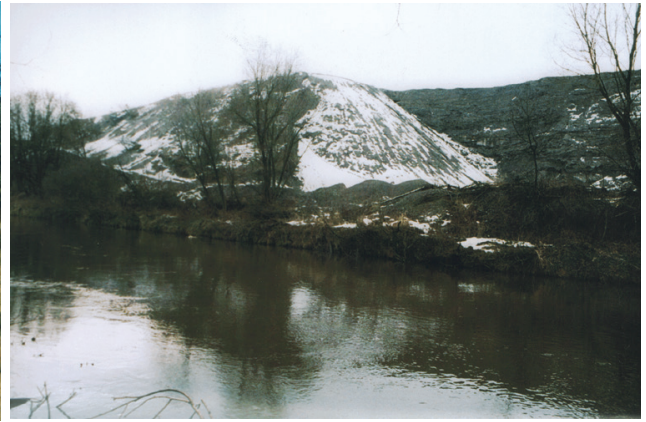

Fot. M. Bożym

d. Widok od strony rzeki, wiosna 2012 r.

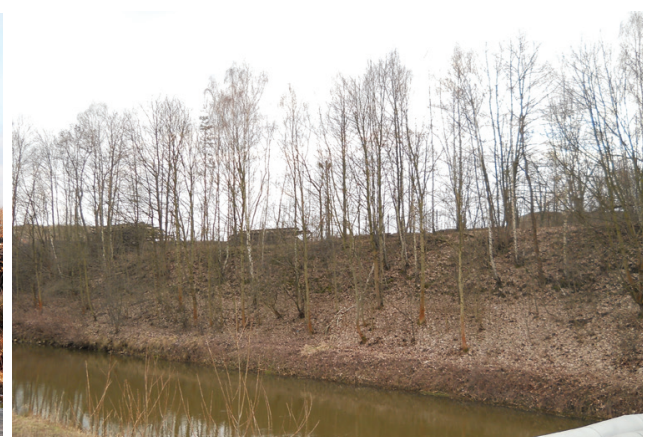

Fot. M. Bożym

f. Widok od strony rzeki, wiosna 2016 r.

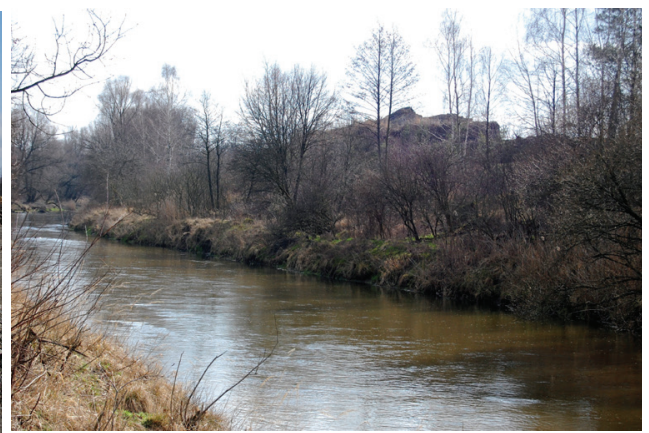

Fot. M. Bożym 
g. Widok z trasy DK46 od strony Opola, lato $2017 \mathrm{r}$.

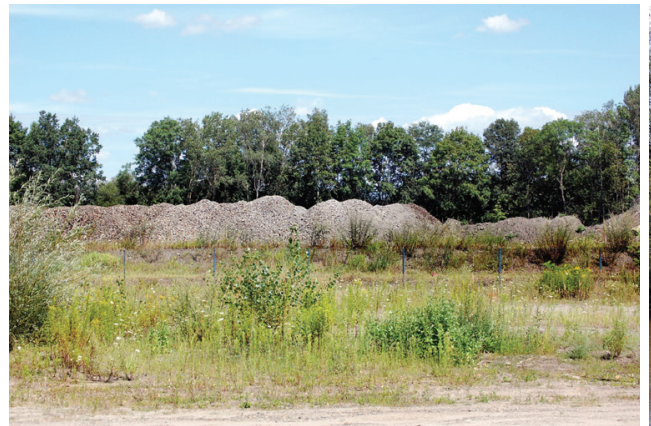

Fot. M. Bożym h. Widok od strony rzeki, lato 2017 r.

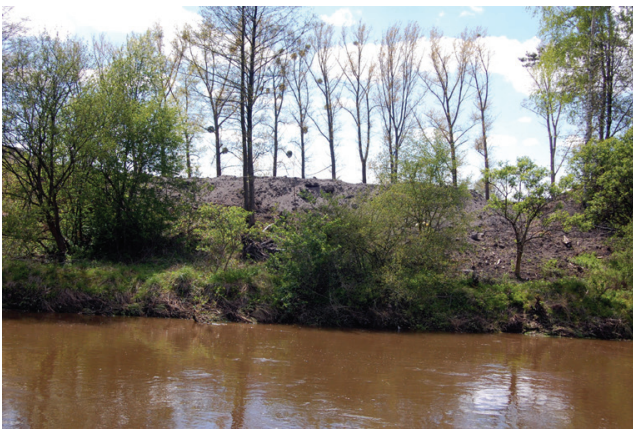

Fot. M. Bożym

\section{Oddziaływanie hałd na środowisko i społeczność lokalną}

Od momentu rozpoczęcia stosowania piasków formierskich do produkcji odlewów, odpady hutnicze wykorzystywano do licznych celów budowlanych, realizowanych na terenie zakładu i miasta. Piaski formierskie ze względu na dobre właściwości mechaniczne były chętnie stosowane do utwardzania dróg, osuszania terenów podmokłych czy wzmacniania gruntów pod budowę osiedli mieszkaniowych oraz terenów rekreacyjnych. Wówczas nie prowadzono specjalistycznych badań nad wpływem tych odpadów na środowisko. Obecnie obowiązujące przepisy prawa wymagają przeprowadzenia oceny takiego wpływu. Na ich podstawie stwierdzono, że odpady te nie wykazują negatywnego wpływu na środowisko i mogą być wykorzystywane do produkcji kruszyw drogowych. Najwięcej odpadów powstało w latach 70. i 80. XX w., czyli w czasach zwiększonej produkcji. Mimo częściowego wykorzystywania odpadów, hałdy nie zmniejszały swoich rozmiarów, a ze względu na to, że huta nie wykorzystywała ponownie zużytych piasków formierskich w procesie produkcji, nawet się powiększały. Wówczas najważniejsze wydawało się osiągnięcie odpowiedniej wielkości produkcji, nie zaś zagospodarowanie odpadów zdeponowanych na hałdach. Dlatego oba zwałowiska zwiększały gabaryty i zajmowały coraz większy teren. Mieszkańcy Ozimka byli przyzwyczajeni do krajobrazu "górskiego", czyli widoku obu hałd, nazywanych "górami Ozimka”. Zmiany polityczne, które zaszły po 1989 r. w kraju, spowodowały zmianę $\mathrm{w}$ postrzeganiu problemów ochrony środowiska, $\mathrm{w}$ tym problem składowanych odpadów. Rocznie zakład produkował około 30 tys. ton odpadów, z czego $75 \%$ to były zużyte masy formierskie i rdzeniowe. W 2005 r. zakład zainwestował w instalację do regeneracji mas formierskich, co zmniejszyło ilość powstających odpadów o 90\%, a tym samym ograniczono koszty produkcji [Baginska 2008; Bożym, Dąbrowska 2012]. Utrzymanie obu składowisk było kosztowne i w tej sytuacji niepotrzebne. Dzięki współpracy z firmą BEHATEX i odzyskowi odpadów, hałdy powoli zaczęły znikać z krajobrazu miasta. Budziło to sporo kontrowersji wśród mieszkańców miasta. Obawiano się, że podczas 
przerabiania odpadów dojdzie do zwiększonego zapylenia oraz zanieczyszczenia wód podziemnych. Obawy nie były uzasadnione. Należy podkreślić, że huta prowadzi ciągły monitoring wpływu obu hałd na środowisko. Wyniki badań wskazują na brak negatywnego oddziaływania zdeponowanych tam odpadów na środowisko. Usytuowanie obu hałd w bliskim sąsiedztwie rzeki Mała Panew, także budziło niepokój mieszkańców, którzy podejrzewali bezpośredni wpływ na jakość wody w rzece i pobliskich Jeziorach Turawskich. Podejrzewano, że to hałdy mogą wpływać na eutrofizację wód w jeziorach. Jednak problem ten wynikał raczej z zanieczyszczenia wód rzeki przez ścieki pochodzące z okolicznych miejscowości i ośrodków turystycznych oraz rolnictwa. Mieszkańcy widzieli także inne zagrożenie ze strony hałd. Przez lata wśród mieszkańców funkcjonowało przekonanie, że na hałdach zdeponowano odpady radioaktywne, które „świecą” w nocy. Okazuje się, że materiał zgromadzony na składowiskach nie ma charakteru radioaktywnego, co w $2004 \mathrm{r}$. potwierdziły badania przeprowadzone na Uniwersytecie Opolskim [Raszyk 2005; Bożym i in. 2009]. Efekt świecenia w nocy to była jedynie łuna światła z pracujących pieców hutniczych, widziana po zmroku. Również charakterystyczny, metaliczny zapach unoszący się nad zakładem, był efektem produkcji odlewów, głównie podczas zalewania form. Mieszkańcy miasta obawiali się także, że podczas przerabiania odpadów na hałdach dojdzie do skażenia środowiska przez metale ciężkie i fenol. Monitoring jakości wód podziemnych wokół składowiska, realizowany przez zakład i kontrolowany przez jednostki inspekcyjne, nie potwierdzają tego zjawiska, a tym samym negatywnego wpływu zdeponowanych odpadów na jakość wód podziemnych. Potwierdziły to także badania przeprowadzone w 2012 r. przez studentów Politechniki Opolskiej [Strózyk 2013; Wolak 2013]. Innym mitem funkcjonującym wśród mieszkańców miasta była historia zakopania w hałdach wartościowych urządzeń, w tym lokomotywy czy całego pociągu. Okazuje się, że firma, która zajmuje się eksploatacją obu składowisk nie natrafiła jeszcze na zakopane urządzenia. Prace eksploatacyjne wciąż trwają. Być może odnajdą się jeszcze „skarby" zakopane w hałdach...

\section{Kultywowanie tradycji hutniczych}

Stopniowa likwidacja zwałowisk, zwanych „Starą" i „Nową hałdą” wpłynęła pozytywnie na przestrzeń miejską Ozimka. Do tej pory przejeżdżających przez Ozimek na trasie OpoleWarszawa witały dwie hałdy usytuowane w poprzek drogi, wraz wiaduktem linii kolejowej łączącej oba składowiska. Widok ten negatywnie wpływał na miejski krajobraz. Nie zawsze tego typu obiekty, jak hałdy przyzakładowe są negatywnie odbierane przez mieszkańców terenów postindustrialnych. Takim przykładem może być małe miasteczko Bruay-surl’Escaut w północnej Francji, w regionie Nord-Pas de Calais, należącym do regionu przemysłowego Bassin Minier. W latach 90. XX w. mieszkańcy nie zgodzili się na likwidację hałdy, tłumacząc to dbałością o relikty przeszłości i tożsamość tego miejsca.

Obecnie obie hałdy niemal zniknęły z przestrzeni miejskiej, co znacznie poprawiło jakość krajobrazu wokół miasta. Teren po większej części składowiska został przekazany gminie. Aktualnie trwają prace nad jego zagospodarowaniem. 
Gmina szuka inwestorów, zainteresowanych zakupem gruntu. Dzięki działalności „Stowarzyszenia Dolina Małej Panwi” i licznym publikacjom autorstwa J.T. Jurosa, turyści odwiedzający Ozimek mogą zapoznać się z historią huty i miasta. W ramach "Spotkań w Dolinie" organizowanych przez Stowarzyszenie, prowadzone są wykłady na temat hutnictwa i historii tych terenów. Do atrakcji miasta należy muzeum hutnictwa. Ponadto członkowie i sympatycy Stowarzyszenia kultywują tradycję "Bractwa Strzeleckiego". W 2009 r. reaktywowano „Ozimskie Towarzystwo Strzeleckie” (MalapanerSchützengilde), które sięga korzeniami początków XIX w., kiedy wybudowano na terenie „Królewskiej Pruskiej Huty Malapane" w Ozimku zakład produkcji elementów do karabinów (zamki, lufy karabinowe, bagnety i stemple do ładowania). Coroczna rywalizacja strzelecka odbywa się w „Parku Hutnika” na wyspie Rehdanza, na specjalnie w tym celu wybudowanej strzelnicy, $\mathrm{z}$ użyciem repliki karabinu produkowanego w hucie. Inne inicjatywy, takie jak organizacja „Święta Mostu i Żeliwa” wraz z pokazem odlewania żeliwa do przygotowanych form odlewniczych, przybliżają pracę hutników. Impreza towarzysząca: „Bitwa o most”, choć nie ma umocowania historycznego, kultywuje obyczaje i dodatkowo przybliża historię miasta i huty.

\section{Podsumowanie}

Całkowita likwidacja hałd przyzakładowych w Ozimku spowodowała zmianę wizerunku miasta, kojarzonego do tej pory $\mathrm{z}$ przemysłem ciężkim. Industrialny krajobraz miasta powoli zmienia się. Nie są to jedyne zmiany przestrzeni miejskiej. Wiele z niedziałających już instalacji, $w$ tym hal produkcyjnych, znajdujących się na terenie huty zostało zlikwidowanych. Większość z nich była przestarzała, wybudowana w latach 60. czy 70. XX w. i nie spełniała wymagań nowoczesnych technologii. Zmiany na terenie zakładu wpłynęły bezpośrednio na przestrzeń miejska, zwłaszcza na obszar przy dworcu PKP. Poza tym dzięki działaniom popularyzacyjnym samorządowców udało się odmienić wizerunek Ozimka, z postindustrialnego na miasto zieleni, z licznymi atrakcjami turystycznymi. Dlatego określenie: „miasto położone wśród lasów i przyjazne środowisku”, wykorzystywane w promocji miasta, wydaje się właściwe. Mimo zmian zachodzących w przestrzeni miejskiej nie zapomniano na szczęście o tradycjach i historii miasta, związanego bezpośrednio z hutnictwem. Huta nadal funkcjonuje, ale już w bardzo ograniczonym zakresie. Włodarze miasta wspierają działalność sympatyków ratujących przed zapomnieniem historię i tradycje tych terenów. 


\section{Literatura}

Baginska E., 2008, Zrównoważony rozwój w praktyce. Huta Małapanew Sp. z o.o. w Ozimku, Ekologia Przemysłowa, 3, s. 54-57.

Bożym M., Staszak D., Majcherczyk T., 2009, Badanie zanieczyszczenia metalami ciężkimi i radionuklidami zwatowisk odpadów odlewniczych w Ozimku oraz ich wptywu na stan okolicznych gleb, Prace Instytutu Szkła, Ceramiki, Materiałów Ogniotrwałych i Budowlanych, 4, s. 107121.

Bożym M., Dąbrowska I., 2012, Kierunki zagospodarowania odpadów odlewniczych, [w:] K. Oszańca (red.) Problemy w ochronie środowiska w województwie opolskim - odpady i ścieki, Atmoterm, Opole, s. 24-41.

Juros J.T., 2010, W dolinie Małej Panwi, historia fryderycjańskiej osady Hutniczej Ozimek/Malapane od 1754 do 1945 roku, Wyd. Stowarzyszenie Dolina Małej Panwi, Ozimek.

Juzwa N. (red.), 2010, Architektura i urbanistyka wspótczesnego przemystu, Gliwice.

Materiały informacyjne UMiG Ozimek, 50-cio lecie nadania praw miejskich, Wydział Architektury Politechniki Śląskiej, Wydawnictwo Astra, www.ozimek.pl, dostęp dnia: 10.05.2016.

Popiołek O.S., 1955, Huta Małapanew 1755-1955, Komitet Obchodu Uroczystości 200-lecia Huty Małapanew w Ozimku, Ozimek.

Raszyk D., 2005, Składowisko odpadów byłej Huty „Małapanew” S.A. w Ozimku jako potencjalne źródło zanieczyszczenia środowiska, praca magisterska, promotor: T. Majcherczyk, Uniwersytet Opolski, Instytut Chemii, Opole.

Stróżyk M., 2013, Określenie możliwości zanieczyszczenia środowiska poprzez stosowanie odpadowych mas formierskich $w$ drogownictwie, praca inżynierska, promotor: M. Bożym, Politechnika Opolska, Wydział Mechaniczny, Opole.

Wolak M., 2013, Określenie zagrożenia zanieczyszczeniem wód podziemnych przez składowanie odpadów odlewniczych na podstawie badania stopnia wymywalności zanieczyszczeń, praca inżynierska, promotor: M. Bożym, Politechnika Opolska, Wydział Mechaniczny, Opole. 


\section{Changing the image of the city through eliminating postindustrial waste heaps}

\section{ABSTRACT}

The article presents changes in the urban landscape caused by the elimination of overhead slag heaps from the "Huta Małapanew" metalworks in the city of Ozimek (Opole Region). The subject was undertaken as a result of the author's long-term cooperation with the industrial plant during which the environmental impact of waste collection on heaps was studied. The author is also a resident of the city in question. The main objective of the study is to present the changes in the urban landscape of post-industrial areas resulting from the elimination of industrial heaps. This is an example of rational urban area management and effective cooperation between the local government and the industrial sector.

The removal of the heaps and the renewal of the post-industrial areas have improved not only the landscape, but also the state of the environment. Reuse of the waste collected in heaps has reduced its environmental impact and the consumption of raw materials. Two slag heaps from "Huta Małapanew" were located across national road no. 46 Opole-Warszawa (DK46), along the Mała Panew river. For many years the heaps were an integral part of the city, creating an industrial landscape. At present, only a small part of the landfill belongs to the foundry and still serves as a site for waste collection. The remaining part of the landfill was sold to a company that specializes in foundry waste recovery and production of road aggregates. Due to the gradual elimination of the heap, the city landscape is constantly improving. The municipality became the owner of a portion of the landfill, and the area was designated for investment. The article describes the origin of the heap and its development against the background of the foundry. In addition, changes to the urban landscape during the heap's elimination are illustrated.

Key words: industry wastes, slag heaps, urban landscape

dr inż. Marta Bożym, specjalizuje się w tematyce zagospodarowania odpadów przemysłowych oraz zanieczyszczeniem środowiska metalami ciężkimi, kontakt do autora: Politechnika Opolska, Wydział Mechaniczny, Katedra Inżynierii Środowiska, ul. Prószkowska 76, 45-758 Opole, e-mail:m.bozym@po.opole.pl

Marta Bożym, PhD eng, specializes in industrial waste management and heavy metal pollution; contact to the author: Opole University of Technology, Faculty of Mechanical Engineering, Department of Environmental Engineering, 76 Prószkowska Street, 45758 Opole, e-mail:m.bozym@po.opole.pl 